\title{
La noción de
}

\section{comunidad aplicada}

a las pandillas

transnacionales* / The

notion of community

applied to transnational

\section{gangs}

*Artículo de reflexión. Recibido: 16 de febrero de 2017. Aceptado: 31 de octubre de 2017. Tla-Melaua, revista de Ciencias Sociales. Facultad de Derecho y Ciencias Sociales. Benemérita Universidad Autónoma de Puebla, México / IssN: 1870-6916 / Nueva Época, año 12, núm. 44, abril-septiembre 2018, pp. 208-240. 
El presente artículo analiza, a través de la tensión entre hospitalidad interna y hostilidad con el exterior, las relaciones al interior de las pandillas transnacionales de El Salvador. El testimonio brindado por miembros de la Pandilla 18 y la Mara Salvatrucha 13 son las fuentes para pensar estas agrupaciones más allá de la asimilación al crimen organizado. A través de la noción lazo-de-deuda se observa cómo la hostilidad exterior impone una forma de hospitalidad de corte comunitario, en un sentido cercano al propuesto por el filósofo italiano Roberto Esposito, es decir, como una violencia hacia la sociedad como formación política. De esta manera, no se niega la proclividad de las pandillas hacia la violencia, sino que se busca comprender cómo esta violencia tiene una potencia creadora y no sólo destructiva.

\section{PALABRAS CLAVE}

Pandillas transnacionales, hospitalidad, comunidad, violencia.
The present article analyzes the tension between internal hospitality and outside hostility, the relations within the transnational gangs of El Salvador. The testimony given by members of Gang 18 and Mara Salvatrucha 13 are the source as to think of these groups as beyond assimilation to organized crime. Through the debt factor notion, it is observed how the external hostility imposes a form of communitybased on hospitality, as to what it is proposed by the Italian philosopher Roberto Esposito, violence towards society as a political formation. In this way, the proclivity of the gangs towards violence is not denied, but it is sought to understand how this violence destructive power also unites these individuals.

KEYWORDS

Transnational gangs, hospitality, community, violence.

\footnotetext{
* Profesor investigador en el Instituto de Ciencias Sociales y Humanidades "Alfonso Vélez Pliego", de la Benemérita Universidad Autónoma de Puebla, México. (hcmor@hotmail.com) orcid.org/0000-00031709-3955
} 

comunitarios de la pandilla / 3. Ética del dolor: los lazos comunitarios del dolor / 4. Homeboy y homegirl: la virilidad como rasgo comunitario / 5. A manera de conclusión / 6. Referencias

\section{INTRODUCCIÓN}

El fenómeno de las pandillas transnacionales está inscrito en las complejidades de la violencia y la vulnerabilidad de poblaciones cuya principal característica es la ausencia de factores sociales e institucionales que les proteja. Las pandillas transnacionales en El Salvador ya no son un fenómeno exclusivamente juvenil; en ellas conviven sujetos de muy diversas edades, que pueden ir de los 10 años hasta quienes pasan de los 50. Se crea una relación de generaciones que, aunada a las mutaciones provocadas por las políticas de criminalización, ha transformado lo que los pandilleros llaman clecha, es decir, la "buena" manera de ser pandilleros.

Se observa una generación adulta entre los 40 y los 60 años. Estos son los miembros originarios, los verdaderos sobrevivientes de las calles de Los Ángeles. La mayoría está en prisión, y quienes están libres han dejado de participar activamente en el barrio, aunque son considerados miembros. Estos son padres y abuelos y algunos se han retirado tanto de sus clicas que son inidentificables o se les permite estar calmados y dedicarse a asuntos distintos. Durante mi investigación conocí a miembros de la MS y la 18 que coincidían en ciertos espacios, algo impensable en estos días.

Otra generación puede ubicarse entre los 25 y 40. También la mayoría se encuentra en prisión, y quienes están libres aún mantienen fuertes vínculos con el barrio. Pero muchos, al ser padres, se han calmado, han buscado formas de vida lejanas a la violencia y el delito. La tercera generación es la de los más jóvenes, a quienes les ha tomado de frente la política de criminalización, el recrudecimiento de la guerra entre pandillas y el aumento de los enfrentamientos con las fuerzas de seguridad. En esta franja de edad están los pandilleros que se han alejado de la llamada clecha. A esto hay que sumarle la división de la Pandilla 18, las legislaciones antimaras y la declaratoria de las pandillas como grupos terroristas. En el siguiente extracto de diario de campo se nota cómo, para un pandillero de la segunda generación, palabrero de una clica de la 18, el asunto impone complejidades al fenómeno, tanto en la calle como al interior de los centros penales. 
De regreso a San Salvador nos detuvimos en un restaurante para comer, o cenar, desde una perspectiva salvadoreña, pues eran, más o menos, las seis de la tarde. Nos sentamos y pedimos, en un momento Little Shell se levantó para hablar con el encargado del restaurante. Mientras comíamos la plática transcurrió sobre el tema del cisma del Barrio 18 entre Sureños y Revolución. Para Little Shell era complicado tomar bando, a mí me enseñaron que sos 18 y nada más. Qué es eso de sureños y revolucionarios. Es paja, pura casaca. Ya no hay clecha. Homeboy, le decía a mi contacto. La división de la pandilla había sucedido años antes y tenía bastante de estarse fraguando, desde que le dieron al Viejo Lin la palabra de todo El Salvador, algo inédito para la Pandilla $18 .{ }^{1}$

Además, es necesario no dejar de lado una cuarta generación, constituida por los hijos de los pandilleros, los más jóvenes, en su mayoría niños. En estricto sentido no pueden ser considerados miembros de los barrios; pero al formar parte de las familias de los pandilleros, la manera en que se territorializan las colonias y centros poblacionales les otorga un lugar específico, vulnerándolos profundamente. Decía, pues, que el fenómeno de las pandillas transnacionales no puede ser pensado únicamente como un fenómeno juvenil. Su complejidad es mucho más elevada, sobre todo si tomamos en cuenta que, según la Dirección General de Estadística y Censos de El Salvador, se calcula la base social de las pandillas transnacionales en alrededor de 500000 personas, algo así como diez por ciento de la población del país. Esto significa que el fenómeno va más allá de un asunto puramente criminal.

Es desde esa postura que se presenta esta propuesta y desde ahí se despliega la metodología elegida. Esto significa que no considero a las pandillas transnacionales como formas del "crimen organizado" o estructuras delincuencias organizadas y el enfoque reconoce "la violencia objetiva, sistemática y sistémica, oculta tras las operaciones de visibilización exacerbada que ubican hoy a las maras o pandillas como centro mercadotécnico de las agendas de gobierno en El Salvador". ${ }^{2}$ Esto no significa que se omita la relación de las pandillas transnacionales con el delito y con crímenes terribles. Significa, en todo caso, reconocer que las pandillas transnacionales, como forma social emergida debido a las relaciones sociales constituyentes del actual sistema de sociedad, son mucho más complejas y no pueden combatirse en términos de una criminología obtusa; tampoco pueden comprenderse a través de unas ciencias sociales puramente funcionalistas.

\footnotetext{
${ }^{1}$ Diario de campo, junio de 2011.

${ }^{2}$ Bengoa Valdés, Ana, "De maras a marabuntas. El miedo como dispositivo gubernamental, una lectura desde El Salvador”, Polis, Revista Latinoamericana, vol. 14, núm. 42.
} 
En primera, porque como formas sociales son válidas; su existencia responde a necesidades producidas por el actual sistema social. En ese sentido, la búsqueda de su destrucción ha implicado mutaciones que las convierten en formas sociales más letales. Rechazo la manufactura de párrafos como el siguiente.

Hay que destacar que las pandillas son organizaciones criminales de prisión, lo que significa que es dentro del sistema carcelario que se originan, crecen, se fortalecen y socializan su cultura. Lo aseverado anteriormente significa que la condena de prisión no se constituye en un factor disuasivo para que los pandilleros desistan de sus actividades ilícitas, por el contrario "servir tiempo" en prisión es una condición "sine qua non" para que el miembro ascienda en la jerarquía pandilleril. En el caso de El Salvador, todos los máximos cabecillas de las pandillas se encuentran en prisión, desde donde dirigen sus estructuras criminales y planifican a nivel estratégico sus operaciones. ${ }^{3}$

Hay que notar en esta redacción no sólo la ignorancia respecto al origen de las pandillas, sino también lo falaz del argumento. En principio, se asume que las pandillas, en general, se originan en la cárceles, lo cual es mentira si entendemos que la reunión de pares que logran agruparse según un nombre y un territorio ha sido investigada desde la década de 1920.

Incluso, el origen de la Mara Salvatrucha 13 desmiente dicha afirmación. No obstante, tiene verdad en el caso de Estados Unidos. Por ejemplo, en California, a partir de la segregación étnica, surgieron redes de pandillas en el norte y sur del estado: la Mexican Mafia, identificada por el número 13 (a la cual pertenecen tanto la MS como la 18) y Nuestra Familia, al norte de California, identificada por el número 14. La cárcel se convirtió en un lugar donde los jóvenes pandilleros lograban vincularse entre los diferentes barrios mediante la pertenencia étnica. Desde ahí, en Estados Unidos, las pandillas crecieron y se fortalecieron. Pero es mentira que haya surgido ahí. Existen evidencias de pandillas surgidas al interior de las rejas, pero no es el caso de las pandillas transnacionales en El Salvador.

Por otro lado, esta afirmación es miope ante el efecto del encarcelamiento masivo de pandilleros recrudecido desde la década del 2000. Ha sido el encarcelamiento masivo lo que ha provocado una reestratificación forzada sobre las pandillas. ${ }^{4}$ Lo anterior las ha mutado hacia formas

\footnotetext{
${ }^{3}$ López Fuentes, Daniel, Las pandillas: Su expansión territorial en El Salvador: 1992-2015, San Salvador, El Salvador, Colegio de Altos Estudios Estratégicos, 2017.

${ }^{4}$ Moreno, Hugo César y Sánchez, Mónica Elivier, "Pandilla 18 y Mara Salvatrucha 13: violencia y desciudadanización", Revista Cultura-Hombre-Sociedad, vol. 22, núm. 2.
} 
más estructuradas y peligrosas, pero sin llegar a consolidarlas en crimen organizado, sino en formas sociales más sofisticadas, en la medida que su supervivencia se complica.

El carácter transnacional de las pandillas Barrio 18 y Mara Salvatrucha 13 es un fenómeno de desterritorialización iniciado en la década de 1980 (quizá un poco antes). Se debe a la migración forzada por las guerras civiles en Centroamérica. Miles de jóvenes huyeron a la ciudad de Los Ángeles, California, y ahí se encontraron con condiciones de marginación social y segregación étnica tan perniciosos que sus posibilidades de desarrollo eran nulas. Relaciones familiares y culturales fracturadas les llevaron a ingresar a diversas pandillas y, para el caso de los salvadoreños, formar la propia.

Tras los acuerdos de paz, sucedió una segunda desterritorialización marcada por la deportación masiva de pandilleros, quienes llegaron a sus países de origen donde la marginación social los recibió. Así, la segregación cultural definió a las pandillas como lugar social de acogida. De esta manera, los barrios se extendieron más allá de California, más allá de Estados Unidos y por México (en las fronteras norte y sur, incluso algunos pandilleros se han asentado por estados del centro, siguiendo las rutas migratorias, pero sin evidencia de que hayan levantado clicas), Guatemala, Honduras y El Salvador (se han descubierto clicas en España). Eso define el carácter transnacional de estas pandillas, como pasa con otras, como los Latin Kings y Ñetas. Estos son fenómenos de desterritorializaciones forzadas por la migración en el esquema del momento actual del sistema de sociedad y no, como algunos refieren, a "alianzas" para el control de rutas de tráfico humano y de drogas.

Asimismo, en el ámbito de la seguridad están consolidando su influencia y poder dos actores que actúan en la ilegalidad: los cárteles mexicanos de narcotráfico y organizaciones criminales que le son serviles y las pandillas. En relación a los primeros, el control de los subsistemas de traslado y distribución de droga hacia el norte se ha trasladado de los carteles colombianos de la droga a los mexicanos. A su vez, la ruta de tránsito marítimo se ha trasladado del Caribe a las aguas del Istmo centroamericano y ante algunos logros en su interdicción, se inicia la utilización del tránsito terrestre a través del territorio centroamericano. En relación con las pandillas, éstas han comenzado a consolidarse como organizaciones criminales de alcance transnacional producto del control que empiezan ejercer sobre las rutas de contrabando y el tráfico humano hacia el norte. ${ }^{5}$

\footnotetext{
${ }^{5}$ Navidad Guillén, Jaime Antonio, Los postconflictos: estabilización y construcción de la paz. Caso de estudio El Salvador, San Salvador, El Salvador, Colegio de Altos Estudios Estratégicos, 2017, p. 12.
} 
No hay que olvidar que el adjetivo transnacional para las pandillas se utilizó, en primera instancia, para argumentar a favor de la consideración de las pandillas como un peligro regional. No es en ese sentido en que lo uso, sino en el que se propuso antes, es decir, como un lugar social comunitario desterritorializado que se territorializa pero se expande siguiendo una lógica cultural y no una lógica económica.

Las pandillas se han transnacionalizado porque se ha forzado a individuos a desterritorializarse, y no porque hayan buscado expandir sus fuerzas. Comprender a las pandillas transnacionales a través de las lógicas culturales que les vertebran es necesario para, primero, imaginar alternativas reales que permitan disminuir la violencia y, segundo, comprender que la empresa no se trata de destruir este tipo de agregación sociocultural, sino de descubrir sus potencialidades para mejorar la calidad de vida de los pandilleros.

En un artículo dedicado a revisar el rol de las mujeres dentro de las pandillas transnacionales, donde queda claro su carácter de subcultura derivada de una cultura hegemónica eminentemente machista, donde los valores de virilidad son fomentados y buscados, incluso por las mismas mujeres.

[...] a causa de la sumisión a la que están sometidas, pero también a causa de las consecuencias que conlleva la huida, las mujeres madres se terminan quedando dentro de la mara. Sus hijos, entonces, crecerán alejados de toda socialización primaria ajena a la de la mara y se nutren casi exclusivamente de una cultura que acuña la violencia y premia la agresión, junto con una serie de conductas ilegales. Su familia es la pandilla y no conocen otra alternativa. Está claro entonces que de allí no surgirán más que nuevas generaciones de mareros, que se encargarán de reproducir el orden social al que pertenecen, que es distinto al vigente en el resto de la sociedad, pero que termina reproduciendo pautas culturales muy fuertes vinculadas al machismo. ${ }^{6}$

Es posible hoy pensar en una cuarta generación de pandilleros: los hijos de quienes hoy pertenecen a los barrios. Las madres de éstos no son sólo homegirls, pues según las relaciones de género en extremo machistas, los homeboys sí pueden tener parejas "civiles", es decir, que no pertenezcan a las pandillas; ellas, no. La situación de las mujeres, ya estén dentro o sean novias, esposas, madres o amigas, es cada vez más vulnerable a medida que la criminalización de las pandillas aumenta.

Como dice Carolina Sampó, la pandilla no sólo es la familia, sino que, como lugar social comunitario, es el espacio de socialización y socialidad

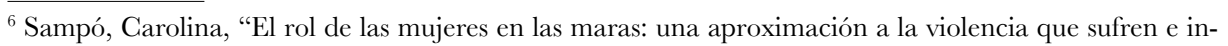
fringen”, Sí Somos Americanos. Revista de Estudios Transfronterizos, vol. 16, núm. 2, 2016, p. 140
} 
exclusivo para muchos niños y jóvenes. El peso poblacional de las pandillas en El Salvador impone la necesidad de repensar el tratamiento del fenómeno en la actualidad. Para que esas mujeres, niños y jóvenes logren descubrir maneras alternativas a la violencia es necesario asumir a las pandillas como una forma de agregación social cuyas oportunidades para recibir a miles de sujetos marginados y segregados pueden ser benéficas para ellos y el resto de la sociedad. Más que destruirlas, se trata de recibirlas y procurar el cambio en su interior.

Estos principios generales definen el acercamiento metodológico, el cual se construyó a partir de técnicas de investigación como la etnografia, la entrevista a profundidad y las historias de vida. Debido a los altos índices de violencia en el campo, las estancias han sido cortas y discontinuas, y se ha utilizado la entrevista telefónica y por medios digitales. Se inició en 2008, con visitas al campo en 2009, 2011 y 2013, con reuniones en México y entrevistas a distancia en 2014 y 2015. Otro encuentro con miembros de pandillas se llevó a cabo en 2016 en el marco de una bienal en Manizales, Colombia.

En principio, entiendo a la pandilla como una forma social y cultural que he denominado deriva comunitaria y un lugar social comunitario, siguiendo la influencia de Roberto Esposito. En cierto sentido, el proceso metodológico es parecido al seguido por otros investigadores como Mauro Cerbino, Luis Barrios y David Brotherton, Carles Feixa, Carlos Mario Perea Restrepo y Alfredo Nateras. Barrios y Brotherton produjeron una metodología que se conoce como criminología cultural "la cual se coloca en las antípodas de la criminalización de los grupos sociales que participan en subculturas urbanas"?

Me adhiero conscientemente a esa premisa, en cuanto estos investigadores "lanzaron el desafio de explorar las conexiones entre crimen, cultura y resistencia. 'La criminología cultural intenta conceptualizar las dinámicas de clases, crimen, y control social en la fluidez cultural del capitalismo contemporáneo; intenta también entender las conexiones entre crimen, activismo y resistencia política bajo esas circunstancias". ${ }^{8}$ Sin embargo, no pretendo hacer una "criminología", sino una sociología que no se ciñe exclusivamente a los aspectos culturales, sino a los efectos políticos de las relaciones entre pandillas transnacionales y el resto de la sociedad. No pretendo comprender prácticas delincuenciales, sino prácticas sociales que han sido criminalizadas a tal grado que generan prácticas delictivas de alto impacto. En cuanto al proceso metodológico, la criminología cultural establece que:

\footnotetext{
${ }^{7}$ Appiolaza, Martín, "Criminología cultural y el trabajo con grupos juveniles violentos como actores sociales del cambio”, en Joaquín A. Mejía Rivera, C. H. Gerardo Ballesteros de León y Josué Murillo (coord..), Violencia, derechos humanos y seguridad ciudadana, Tegucigalpa, Casa San Ignacio - Guaymuras, 2014, p. 50. ${ }^{8}$ Idem, p. 51.
} 
para entender el delito desde una perspectiva alternativa [es preciso]: (a) Mezclar lo instantáneo con el largo plazo; (b) Estar en sintonía con la imagen, abandonando los métodos de las ciencias sociales que privilegiaban el contenido sobre la forma. En la investigación del crimen hay que privilegiar la imagen sobre la palabra (atender lo simbólico, lo gestual, otorgando menos peso al análisis discursivo de los transgresores); (c) Conexión con métodos de producción de imagen y métodos de producción más literarios o artísticos que científicos. ${ }^{9}$

Estoy de acuerdo con la propuesta, sobre todo con el primer punto. En cuanto a los segundos, esto se complica en situaciones de elevada violencia. Además, considero que el discurso de los sujetos es central, pues ahí lo simbólico se torna realidad, sin desestimar lo gestual, corporal y el conjunto de signos que acompañan a la palabra. Esto se consigue con el último punto: la producción artística. Sin embargo, para lograr esto se precisa de estancias largas, como la que consiguió Christian Poveda. El caso es elocuente por sí mismo, tanto el proceso y el producto, como el desenlace.

En mi caso, ha sido imposible una estancia más larga que un par de meses. En tal lapso fue imposible implementar talleres, sobre todo de creación literaria, lo cual propuse a Homies Unidos, pero no se logró debido a la desaparición de la organización. Por ello, la entrevista a profundidad y la historia de vida, donde omití deliberadamente preguntas directas sobre actividades violentas, han funcionado como una suerte de narrativa. De ahí que la palabra me siga pareciendo central para el estudio de este tipo de fenómenos. Algunas anécdotas permiten la sensación literaria.

Otro aspecto en que me distancio de la propuesta de Barrios y Brotherton (que es también asumida por Cerbino y, en cierto grado, por Feixa), es en la consideración de las pandillas como organizaciones de la calle: "la criminología cultural aporta una perspectiva alternativa de los grupos juveniles afectados por la violencia, entendiéndolos como organizaciones más que como comportamientos individuales".

$\mathrm{Al}$ definir a las pandillas como lugar social comunitario quiero alejarme de la idea de organización. Organización refiere al agrupamiento realizado para perseguir y alcanzar una meta específica, para lo cual se brindan protocolos y se asigna a sus miembros funciones. Es posible que las pandillas observadas por Cerbino, Feixa, Barrios y Brotherton, como los Latin Kings, tengan, debido a su estructura piramidal, una forma de organización y eso permita imaginarlas como tal. Pero considero que las pandillas no son organizaciones, sino una tensión entre cuerpo sin órganos y una relación comunitaria

${ }^{9}$ Idem, p. 52 . 
que siempre está, al ser criminalizada, reestratificandose. ${ }^{10}$ Considero que lo anterior presenta la oportunidad de pensar a las pandillas como una oportunidad alternativa de desarrollo a la familia, la escuela y las iglesias, que han fallado y han dado paso a las pandillas como lugar de socialidad y socialización. Por ello, es necesario entenderlas de otra manera, para evitar sentencias como esta:

Esto acarea [sic] que los jóvenes que deciden y optan formar parte de estructuras delictivas, tienen un comportamiento diferente, han perdido todo respeto a la autoridad familiar, no aceptan ningún tipo de norma, no muestran valores, la conducta mostrada es total desorientación, aunado que viven en hogares hostiles. ${ }^{11}$

Si algo pasa con los jóvenes que ingresan a las pandillas es que entran a un lugar social donde existen reglas y principios de convivencia que deben seguir a riesgo de ser penalizados por sus pares. Para muchos jóvenes, es en las pandillas donde comprenden valores y principios de convivencia, donde alcanzan cohesión social y cultural y donde logran ser considerados, reconocidos y respetados. Las instituciones del resto de la sociedad sólo los han marginado; la pandilla les recibe y les brinda un lugar donde pueden dar sentido a su vida. Por supuesto, todo esto sucede en ámbitos sumamente violentos. No se trata de una apología de las pandillas, sino de pensar en otra forma de acercamiento teórico, metodológico y de política pública.

Desde estos principios metodológicos, la lógica puramente individual permite rechazar acercamientos puramente criminalizantes para pensar en las pandillas transnacionales como un lugar social comunitario que suple las falencias de las instituciones clásicas del sistema de sociedad. Familia, trabajo, escuela, iglesia y otras formas son rechazadas en cuanto le son negadas de manera estructural.

Estamos en desacuerdo con las visiones que asumen la pertenencia a este tipo de pandillas como si se tratara de la total ausencia de valores. Lo cual es una postura miope, pues si algo ofrece la pandilla es, precisamente, una serie de valores que le dan sentido a la pertenencia y hacen de la relación un lugar social comunitario. La producción de valores propios es la principal fuente de hostilidad ante el resto de la sociedad, pues son valores opuestos a los otorgados por el sistema social. Por ello, es absurdo pensar que la pertenencia al barrio se da de manera hereditaria. Hay, sí, un fenómeno interesante respecto a los hijos de los pandilleros, pero no está en la supuesta

\footnotetext{
${ }^{10}$ Moreno, Hugo César y Sánchez, Mónica Elivier, Homies Unidos: Estrategias de reestratificación desde la sociedad civil, México, Universidad Iberoamericana, 2018.

${ }^{11}$ López Fuentes, Daniel, op. cit.
} 
pertenencia hereditaria, sino en las formas en que son niños y jóvenes vulnerados desde el principio de sus vidas (como hijos de madres encarceladas y padres buscados, huérfanos educados por el entorno pandillero, con relaciones conflictivas en la escuela).

Que las pandillas carezcan de una orientación de persistencia cultural más allá de la cotidianidad tiene que ver con cómo valoramos el tiempo, el cuerpo y el trabajo en términos modernos, tardomodernos o neoliberales. La pandilla abre espacios y territorios distintos a los que vive el resto de la sociedad. Para muchos jóvenes, la pandilla es el primer lugar donde encuentran sentido y orden, valores y reglas, objetivos y metas.

\section{HOSPITALIDAD-HOSTILIDAD:}

\section{LOS BORDES COMUNITARIOS DE LA PANDILLA}

La pandilla es comunidad ética. La pertenencia se define en un darlo todo, volcarse al otro, a los otros, a los homeboys, como si se tratara de una unidad. Entre el sobrevivir para la amistad y por la amistad, existe un lazo-de-deuda, líneas que unen y envuelven al colectivo extendido por el barrio, más allá de la esquina, más allá de la clica, el número o las letras acomunan. En la supervivencia, la comunidad pandillera hiere al resto de la sociedad y el vínculo hospitalidad-hostilidad fortalece los lazos.

Gorila $^{12}$ es un pandillero del Barrio 18. Está calmado. ${ }^{13}$ Él entiende el péndulo hospitalidad-hostilidad cuando me explica que "para llegar a sobrevivir en este ambiente necesitás manejar muchos escenarios: la sociedad, la rivalidad, la autoridad". ${ }^{14}$ En ese cruce de "escenarios", de "realidades", la supervivencia se instala entre la hospitalidad-hostilidad, según el grado de marginación alcanzado por la pandilla, que para 2016 se trata del más elevado según las políticas de criminalización salvadoreñas. Los entendidos de los noventa, incluso de la primera década del siglo XxI, han desaparecido: la sociedad está cada vez más indispuesta para percibir a los pandilleros como algo más que criminales. La rivalidad entre la Pandilla o Barrio 18 y la Mara Salvatrucha 13 es cada vez más sangrienta; y la autoridad tiene como única visión del fenómeno una política criminal anclada en los presupuestos del derecho penal del enemigo.

\footnotetext{
${ }^{12}$ Gorila, entrevista personal, junio 2009.

${ }^{13}$ Según las reglas de las pandillas, la salida del grupo sólo sucede con la muerte. Después de los procesos de criminalización acentuados a partir del Plan Mano Dura (2003) y Súper Mano Dura (2005), tanto la Pandilla 18 como la Mara Salvatrucha 13 aceptaron que los miembros con intenciones de abandonar la violencia dejaran de participar activamente dentro de las pandillas. A estos miembros se les conoce en el argot pandillero como calmados.

${ }^{14}$ Ibidem.
} 
En ese contexto, explica Gorila: "hay muchas cosas que tenés que saber manejar, en ese contexto es de que se juega un papel trascendental el pensamiento de cada uno, cada soldado ejerce una acción".${ }^{15}$ El lenguaje bélico implica la tensión hospitalidad-hostilidad, en quién confiar, en quién sostenerse. El amigo, el homeboy, el hermano es también un soldado, un hostil, un cuerpo que desde la hospitalidad se forja para la respuesta hostil. Frente a la cada vez mayor hostilidad del exterior, las pandillas han reaccionado con reglas más estrictas para la pertenencia y permanencia en su interior.

Las consecuencias son, a sus acciones su debida consecuencia, entonces hay unos que se meten a esto porque les gusta andar vacilando, pero ellos no saben mucho como de qué se trata hasta cuando ya están aquí adentro ya ven, más bien, no es que no sepan, pero no saben muy bien. Ahora, cuando ya están en esto ya ven bien qué es lo que quieren, de qué se trata y les gusta, ahora, al que no le gusta nadie le obliga, porque aquí hay que entender algo, aquí con respeto y honra entra un miembro de la pandilla [Comunidad elegida] y así sale el día que quiera. ${ }^{16}$

Gorila, en otros momentos, dejará ver que esa supuesta salida no es tersa y sólo es posible bajo ciertas circunstancias. A la pandilla se le elige, y al hacerlo se acepta la pertenencia absoluta y que se sale sólo muerto. La modalidad de pandillero calmado no implica la salida de la pandilla. El mismo Gorila se define como un pandillero no activo en violencia. La salida diluye el lazo, lo rompe: pero no se sale si el respeto y la honra definen la membresía elegida: es la muerte la única salida honrosa. Las otras salidas se abren con la traición y también con la muerte. "Ahora, si hace una cosa que esté mal, hay una regla que lo va a castigar. Como en la sociedad, en la sociedad hay unas reglas que se llaman leyes, que son las que juzgan. El humano lo único que hace es apegarse a esas leyes y ejecutarlas". ${ }^{17}$

Claramente, estas "leyes de la sociedad" no son las de la pandilla. Aquí es notable la tensión hospitalidad-hostilidad que atraviesa a la pandilla. Gorila dice "el humano", distinto al "soldado"; pero el homeboy es humano y soldado, está en el barrio y en la sociedad. Como soldado de la pandilla, la sociedad le es hostil; como humano reconoce la ley, su juicio, su derecho, pero le es hostil, él es hostil y ella es hostil. Cuando Gorila argumenta que "igual es en un reglamento en una empresa, en un reglamento en una institución escolar, en un reglamento en cualquier lugar, que el que la quebranta paga", ${ }^{18}$ deja

\footnotetext{
${ }^{15}$ Ibidem.

${ }^{16}$ Ibidem.

${ }^{17}$ Ibidem.

${ }^{18}$ Ibidem.
} 
percibir que sólo a través de la sanción es posible la ley, y para que esto sea posible el sujeto debe estar enterado de las reglas que conlleva pertenecer, en este caso, a la pandilla. Tales reglas son elementales para fortalecer el lazo con el cual se mantienen fuera de las otras leyes que les impelen sólo de manera hostil.

Esta visión es consecuente con la mirada de Rossana Reguillo. Para ella, las pandillas crean una "paralegalidad", más que una ilegalidad, pues constituyen instituciones desde abajo para enfrentarlas a los ejercicios de poder de arriba. Así, se entiende que su situación es de profunda verticalidad y, por ende, sus ejercicios de resistencia serán más rudos.

La mara opera bajo una lógica cultural y no bajo una lógica legal, porque funda su propia legalidad, es decir, es portadora de un poder paralegal que destroza la oposición binaria legal-ilegal. Lo que para la norma, la ley, o el sentido de lo permitido instalado, más o menos de manera generalizada, es estado de excepción, en la mara es cotidianidad. ${ }^{19}$

Se definen líneas de acción, lo aceptable y lo inaceptable. El barrio rifa, pero el libre albedrío impera, como en varias ocasiones me hicieron notar mis informantes. Su libertad se pone en contra, ataca, espanta y se apodera; "pienso que el poder de la 'paralegalidad' es mucho mayor que el poder de la ilegalidad, ya que la primera lleva implícito el germen de un orden diferente y fundante, paralelo". ${ }^{20}$ La desviación, sin su sentido inmunitario, aunque claramente virulento al ser voluntad de ir a la contra. En las pandillas las lógicas culturales a que se refiere Reguillo, se regodean en el abandono, en su doble sentido, bajo el imperio de la ley y bajo el imperio de la impunidad. Ante unas reglas tan simples y crudas, circunscritas en la tensión hospitalidad-hostilidad del contexto "la sociedad, la rivalidad, la autoridad", el criterio del perdón queda reducido para definir los contornos de la hospitalidad.

Si ahí dice "si robó a los mismos de la pandilla, hay que matarlo", sabiendo él que iba a haber un castigo no se puede perdonar, porque, a diferencia de las otras sociedades, la pandilla no tiene mucho criterio del perdón. No tiene mucho, no es que no exista, pero ahí son los méritos, los que dan: este es buen soldado, ha hecho buenas acciones, ha hecho esto y ha demostrado que merece una oportunidad. ${ }^{21}$

\footnotetext{
${ }^{19}$ Reguillo, Cruz Rossana, "La mara: contingencia y afiliación con el exceso (re-pensando los límites)", en José Manuel Valenzuela Arce, Alfredo Nateras Domínguez y Rossana Reguillo Cruz (coords.), Las Maras: identidades juveniles al límite, México, UAM - Colef -Juan Pablos, 2007, p. 317.

${ }^{20}$ Idem, p. 319.

${ }^{21}$ Gorila, entrevista personal, junio 2009.
} 
$\mathrm{Si}$, como dice Derrida, "el perdón perdona sólo lo imperdonable"22 y la ley de la pandilla es clara, implícita en lo explícito de la hospitalidad-hostilidad, el perdón se otorga sólo sí es concedido al culpable en tanto culpable de provocar un déficit de hospitalidad con referencia al frente hostil (recubrimiento hostil: la sociedad, la rivalidad, la autoridad) y, en la relación, pero a la inversa, ha hecho de la hospitalidad un refuerzo contra ese afuera hostil, según sus "acciones" que, de por sí, son imperdonables en dicho afuera.

"Pero cómo le vas a dar una oportunidad a un borrachito drogadicto. Mejor quitarlo de la sociedad, para que no esté molestando a la misma sociedad y que por este tipo de personas que anda robando del tendedero ropa o de los lavamanos la ropa, tienen mal tildado a los demás miembros de las pandillas". ${ }^{23}$ Se perdona lo imperdonable, se niega el perdón a quien no lo solicita según acciones hostiles contra lo hostil que disminuyen el cerco de hospitalidad de la pandilla.

En la pandilla no hay culpa, hay transgresiones; es decir, incumplimientos con la deuda contraída al momento del brinco, porque "sabiendo él que iba a haber un castigo no se puede perdonar" ${ }^{24}$ Es decir, al pactarse con el barrio, se sabe que al barrio no se le traiciona, pues es traición para él mismo. No se perdona por imperdonable y cuando se perdona es, precisamente, por imperdonable, porque se acredita, se le da crédito, se confía en que la transgresión a la deuda contraída puede equipararse. Es culpable, pero puede pagar la falta.

La magnitud del castigo tiene que ver con la potencia del grupo. La cerradura del barrio hacia el exterior se comprende con relación a la hostilidad y de ahí también la potencia como cohesión y hospitalidad. De ahí que el perdón se otorgue al homeboy a partir de qué tan hospitalario haya sido hacia dentro y qué tan hostil hacia afuera. El problema del perdón y la compasión como esencia de una comunidad ética se juega en la pandilla a través de esa tensión. Es necesario mantener la seguridad del grupo; la sociedad, la rivalidad y la autoridad están siempre de frente. El buen soldado que sabe sortear los peligros y llevar buenas cuentas a la pandilla puede ser perdonado.

Hay una regla, pero también está algo que se conoce como la sana crítica, el criterio, entonces los jóvenes del grupo de donde él es hacen una reunión amplia y dicen este hizo tal cosa apegada a tal regla de tal número, pero consideramos nosotros traer esto a mención, tal vez uno dice, yo levanto la mano, pide palabra, dice, "yo, con respeto para todos, considero que fulano es buen elemento, lo que lo hizo lo hizo,

\footnotetext{
${ }^{22}$ Derrida, Jaques, El siglo y el perdón. Seguido de fe y saber, Buenos Aires, Ediciones de la flor, 2006, p. 13.

${ }^{23}$ Gorila, entrevista personal, junio 2009.

${ }^{24}$ Ibidem.
} 
andaba bolo ${ }^{25}$ o cualquier situación, considero de que no debiera de pagar de esa manera el castigo, no hay que golpearlo". ${ }^{26}$

Derrida señala respecto a quién tiene el derecho a perdonar que "el cuerpo anónimo del Estado o de una institución pública no puede perdonar. No tiene ni el derecho ni el poder de hacerlo [...] El representante del Estado puede juzgar, pero el perdón no tiene nada que ver con el juicio, justamente". ${ }^{27}$ Aquí el perdón castiga, cobra una deuda, y en la deuda el lazo se mantiene; en el pago doloroso la deuda se disuelve y el homeboy transgresor reinicia buscando el beneficio de su clica. "Entonces qué vamos a hacer con él, lo ponen a vigilar, lo ponen, bueno, cualquier cosa, pero que no sea un castigo humillante. Ahora, cuando la transgresión es más grande, también se han perdonado vidas". ${ }^{28}$ Sin embargo, hay transgresiones imperdonables, en toda la pesadez de lo imposible; pero se han perdonado vidas, aun a pesar de la crudeza de las reglas, aun a pesar de ese poco criterio del perdón.

La hospitalidad-hostilidad de la pandilla está en esa tensión del perdón y lo imperdonable. No se perdona, dice Gorila, "soplar, ser ratas", abrir la hospitalidad del barrio a la hostilidad de la sociedad, la rivalidad y la autoridad, poner en peligro a los homeboys, ya sea a la muerte o la cárcel. Borrarse el barrio, es decir, retirarse los tatuajes donde números (18) o letras (Ms) determinan la pertenencia absoluta al barrio, es aún peor a la traición del soplo. Pero, dice Gorila, "hay otras, hay otras. ¡Ah!, ser homosexual adentro de la pandilla. No, no está permitido". ${ }^{29}$ Ambas pandillas son homofóbicas. No es regla de la pandilla la agresión a los homosexuales, no es práctica común, no es rutina. La homofobia de los pandilleros es al interior: no puede existir un pandillero homosexual, según Gorila, "por la misma ideología de las pandillas, aquí no hay homosexualismo. Ahora, no somos sexistas, pero no nos interesa la vida de los demás, nos interesa la vida de nuestros soldados, y por una manzana se van a arruinar las demás" ${ }^{30}$

Ser homosexual dentro del barrio es imposible, por tanto, imperdonable: "No, es que no se transmite, pero si tenemos una persona que roba dentro de la pandilla, dicen que todos los pandilleros son ladrones". Es interesante cómo se recurre a una situación como el robo para justificar una repugnancia de corte moral hacia la homosexualidad. La actividad delictiva es una rutina de cualquier pandilla, es una rutina, no sus líneas de vinculación y desterritorialización. Gorila no es el único que indica el delito, en este caso

\footnotetext{
${ }^{25}$ Borracho.

${ }^{26}$ Gorila, entrevista personal, junio 2009.

${ }^{27}$ Derrida, Jaques, El siglo y el perdón, op. cit. p. 23.

${ }^{28}$ Gorila, entrevista personal, junio 2009.

${ }^{29}$ Gorila, entrevista personal, junio 2009.

${ }^{30}$ Ibidem.
} 
el robo, como algo incluso opuesto al Barrio, pero no prohibido con dureza, distinto a la homosexualidad: "y si tenemos un homosexual van a decir que todos somos homosexuales, y es que no se transmite, pero vivimos bajo la opinión pública, si ves que uno toma, para la gente todos son bolos, si ven que uno pipeya ${ }^{31}$ dicen que todos son drogadictos, y hay elementos que no son drogadictos". 32

El barrio convive con el "mal" designado; lo ubica. No trata de convertirlo en algo mejor, es reflejo del cuerpo de la sociedad y en dicho reflejo inventa "maldades" insoportables, con un exceso de masculinidad montado en la violencia. La homosexualidad es representada como masculinidad reducida $\mathrm{y}$, al mismo tiempo, como rasgo insoportable para el rostro pandillero presentado a la opinión pública.

Yo no tomo ni fumo, pero como los demás lo hacen ellos dicen que todos los pandilleros somos así, te dice alguien "ey mirá", "no, yo no tomo". No le creen a uno. Ahora van a creer que por dos tres semillitas que anden ahí diseminadas los demás van a ser tildados, uno. Número dos, ya hay una regla y las reglas se hicieron para respetarse, no para quebrantarse. ${ }^{33}$

Los pandilleros buscan evadir la ley de la sociedad, pero no perdonan la transgresión de una regla elegida. Esa paralegalidad es más potente, incluso, que la ilegalidad en la que caen al imponer sus propias reglas. " ¿Si alguien es un buen soldado y es homosexual?", me atreví a preguntar.

No existe eso. No existe eso. A diferencia de algunas culturas, otras se han venido modificando. Yo considero de que en las pandillas y los que han sido, sabiendo tenían que haber huido o se hubieran desertado de la pandilla, pero aun así, hicieron con su situación sexualmente hablando, quedarse en un ambiente que sabían que si al descubrírseles se les iba a penar con la pena capital y siguieron jugando al gato y al ratón. Estaban retando a una pandilla, entonces la pandilla lo que iba a hacer era cortar desde la raíz. No hay perdón. Era doble transgresión, una a la regla y otra a la cara de la pandilla. ${ }^{34}$

La homosexualidad se asume, entonces, como una imposibilidad al interior, algo hostil.

\footnotetext{
${ }^{31}$ Fumar crack en pipa.

${ }^{32}$ Ibidem.

${ }^{33}$ Ibidem.

${ }^{34}$ Ibidem.
} 


\section{3. ÉTICA DEL DOLOR:}

\section{LOS LAZOS COMUNITARIOS DEL DOLOR}

No nos ocuparemos del porqué de la homofobia de las pandillas viene a colación con referencia a la tensión hospitalidad-hostilidad y la eticidad de la comunidad pandillera carente de compasión si aceptamos, con Negri, que ésta es la partícula fundacional de toda ética. Sin embargo, en términos de enlazamiento a través de la deuda, los pandilleros producen una ética a través del respeto al barrio. Es una ética sanguinolenta y dolorosa, ahí está su potencia. Recuperando a Negri, "la potencia está instaurada en el dolor: es una potencia del no Ser, una potencia de la comunidad: una esencia incompleta en el seno de un proceso creativo hasta el infinito". ${ }^{35}$ La potencia está en la constitución de un cuerpo colectivo sin centro, un no ser.

Pero el homeboy muerto no sale de la pandilla, se le incorpora en el tatuaje o con la venganza. El ideal de pandilla es la muerte. El dolor es potencia de comunidad en cuanto proceso creativo de línea de fuga perdiéndose en la muerte. La pandilla es creativa, pero enfrentada a la sociedad, la policía y al adversario, para no ser. Para hacer comunidad tiende a la destrucción. "Esta copresencia de la vida y de la muerte, de la potencia y del acto, es una producción de la comunidad, una acumulación extraordinaria de posibilidades". ${ }^{36}$

Gorila hace referencia a la afrenta de borrarse el barrio debido a la exigencia de organizaciones de la sociedad civil oferentes de apoyo a jóvenes pandilleros en "reinserción", de borrarse los tatuajes para ser "sujetos" de apoyo. Se les exige renunciar a su comunidad elegida. Lo imperdonable. Ese es sólo un ejemplo sobre cómo se coartan las posibilidades creativas de la pandilla: para no criminalizarte, exijo renuncies a lo que te convierte en criminal. Al judío no podía exigírsele borrarse la etnia. No eligió su nacimiento. El pandillero elige su barrio; por tanto, en apariencia, puede exigírsele borrarlo. Sólo se le envía a la muerte, al pago de la deuda, porque los pandilleros no tienen reglas para crear culpables, sino para cobrar faltas.

El lenguaje de los pandilleros, sus reglas, su compasión y su falta de ella, los coloca fuera de la sociedad, a pesar de estar implicados en el entramado de las líneas sociales. Caz, un pandillero activo de la 18, me dice: "La gente así me ve, men. Fuera de la sociedad. Yo no me hago fuera, porque estoy dentro de todo el núcleo de todas las personas que conviven. no me siento fuera ni discriminado, simplemente estoy ahí, que la sociedad nos quiere discriminar es otra onda, men, pero nosotros somos igual que cualquier otras persona". ${ }^{37}$

\footnotetext{
${ }^{35}$ Negri, Antonio, fob: La fuerza del esclavo, Buenos Aires, Paidós, p. 162.

${ }^{36}$ Ibidem.

${ }^{37} \mathrm{Caz}$, entrevista personal, julio 2009.
} 
Pero lo que sí tengo que reconocer es que la sociedad te rechaza, como joven y como pobre, y lo que necesitamos nosotros es sentirnos queridos y, lastimosamente, las pandillas se han vuelto un buen centro de recepción de es ese montón de gente excluida. Recepción, las pandillas no reclutan a nadie. Lo que la sociedad rechaza en algún lugar tiene que ir a parar, los desechos que tenemos a diario los humanos, en algún lugar tienen que ir a parar. Lo que nosotros arrojamos del cuerpo en algún lugar va a parar. Entonces, lo que las sociedades marginan, rechazan, desalojan, tiene que ir a parar en algún lugar, para sobrevivir, porque estas personas son vulnerables a comparación de las otras que las han excluido, que tienen un poder. Tienen que agruparse para lograr alcanzar ese poder. ${ }^{38}$

Gorila no sabe explicarme racionalmente por qué él entró a la pandilla "siento que ya estaba $[\ldots]$ predestinado para eso". Recurre a la figura cristianaprotestante de la predestinación para explicar su elección. Después de intentar racionalizar su lugar afuera de la sociedad, explora en la expulsión forzada, en lo que Bauman ${ }^{39}$ llama producción de desechos sociales. La sociedad expulsa, desecha, crea el margen y desde ahí supone una imposibilidad para la creación desde el margen, pues ésta ha sido expropiada por el capital-saber, saber-poder, el discurso universitario.

Pero "en algún lugar tiene que ir a parar" lo marginado y segregado (segregare), lo separado, o producido como secreción, en el mismo sentido de separación. No tiene desperdicio el símil de Gorila con la excreción o desalojo del cuerpo. El cuerpo de la sociedad caga y "lo que las sociedades marginan, rechazan, desalojan, tiene que ir a parar en algún lugar". Esposito afirma que el "pasaje del estado de naturaleza al civil determinado por la instauración del Estado Leviatán" se halla en "la anulación de la nada que la comunidad lleva naturalmente dentro de sí mediante la producción de una nada artificial capaz de reconvertirla en términos ya no destructivos sino ordenadores". ${ }^{40}$ La comunidad es autodestructiva o lleva a una deriva de autodestrucción, a una nada, un vacío de la muerte. Las subjetividades se desubjetivan cuando un lazo se tiene demasiado exteriorizado, cuando hay no ser (si es posible), o no persona. El mismo Esposito refiere con relación a Deleuze, a partir de la ecceidad, una individuación-acontecimiento, una apertura "una aptitud para la composición con otras fuerzas, de cuyo efecto, o afecto, son objeto, transformándose y transformándolas en individualidades más complejas,

\footnotetext{
$\overline{{ }^{38} \text { Gorila, entrevista personal, junio } 2009 .}$

${ }^{39}$ Bauman, Zigmunt, Globalización, consecuencias humanas, México, Fondo de Cultura Económica, 1999.

${ }^{40}$ Esposito, Roberto, Immunitas. Protección y negación de la vida, Buenos Aires, Amorrortu, 2005, p. 124.
} 
sujetas ellas mismas a la posibilidad de ulteriores transformaciones". ${ }^{41}$ A esto podemos llamarlo sujeto explosivo, estallado, reventando la forma esférica del sujeto moderno, ${ }^{42}$ producto del proceso de interiorizaciones de lo social, lo económico y lo político. "Es decir, el orden político de la soberanía se vuelve posible sólo merced a la drástica eliminación de toda relación social externa al intercambio estrictamente individual, entre protección y obediencia". ${ }^{43}$ Con la eliminación de un lazo exteriorizante, una línea de fuga creativa que permita constantes transformaciones subjetivas se constituye el lazo-social de la sociedad. Se elimina a la comunidad para que exista sociedad.

¿La comunidad es una contra-sociedad? Responder afirmativamente es temerario, como si la sociedad fuera "originada" a partir de ese pacto mítico hobbesiano (o rousseaniano o lockeano) y, entonces, lo anterior (estado de naturaleza o de guerra) no estuviera cerca de ser sociedad. La comunidad como no sociedad, incluso como contra-sociedad.

Pierre Clastres distingue dos tipos de sociedad, una con Estado (Leviatán, el contrato social) y otra $\sin$ Estado. Sociedades primitivas y sociedades civilizadas. Las primeras, en plano negativo, carecen y, por tanto, casi no son. Es decir, son pre-sociedades, sin economía de mercado, sin, sin... y en esas carencias está su imposibilidad de ser sociedades: "parecen ser dos los axiomas que guían la marcha de la civilización occidental desde sus comienzos: el primero plantea que la verdadera sociedad se desarrolla bajo la sombra protectora del Estado: el segundo enuncia un imperativo categórico: hay que trabajar". ${ }^{44}$

Sin embargo, Clastres asume que las sociedades sin Estado no lo son por carencia sino como forma de organización. Rechazan el Estado, evitan la formación de poder político, se oponen al Uno como mal, a la unificación bajo el signo de un Estado. Si bien la aparición del Estado es una revolución, sucede como la muerte de las sociedades primitivas. Sin duda, bajo esta óptica, sociedades sin Estado y contra él, en su primitivismo, su tamaño y estructura (no clasista y sin poder político) la voluntad de ir a la contra "de exorcizar lo que está destinado a matarla: el poder y el respeto al poder". ${ }^{45}$ La sociedad está contra el Estado. Una contra-sociedad estatal.

Entonces, la comunidad es una contra-sociedad si nos atenemos a los dos axiomas expuestos por Clastres. La pandilla no es una sociedad salvaje ni una comunidad disuelta para formar a la sociedad con Estado. En principio, como

\footnotetext{
${ }^{41}$ Esposito, Roberto, Tercera persona. Política de la vida y filosofia de lo impersonal, Buenos Aires, Amorrortu, 2009, p. 213.

${ }^{42}$ Moreno, Hugo César, "La vida en contra: apuntes para una teoría sobre el fenómeno de las pandillas transnacionales en El Salvador”, Revista Internacional de Investigación y Docencia, núm. 1, pp. 1-11.

${ }^{43}$ Esposito, Roberto, Immunitas... op. cit., p. 124.

${ }^{44}$ Clastres, Pierre, La sociedad contra el Estado, Barcelona, Monte Ávila, 1978, p. 169.

${ }^{45}$ Idem, p. 173.
} 
dice Gorila, esos desechos buscan sobrevivir. Los desechos de una sociedad con un Estado cada vez más penal, donde la economía se superpone a la política y el mercado rige "tienen que agruparse para lograr alcanzar ese poder", ${ }^{46}$ ese poder que no tienen, ese no-poder que, cuando se conjuga con "ese temor que generan en las personas es lo que las mantiene vivas", ${ }^{4}$ las pasa al ejercicio de un contrapoder, los convierte en una contra-sociedad, en una comunidad ¿Por qué si lo salvaje se opone a la constitución de un poder? Porque la pandilla es un neoarcaísmo trágico, rasgo posmoderno, según Maffesoli, ${ }^{48}$ y no es anterior ni superviviente, es una aparición, si se quiere, una producción, secreción del cuerpo social capitalista.

La pandilla va a la contra como aparición, no como fantasma, pasado u origen glorioso. No es regresión salvaje, sino aparición salvaje, nueva, impelida por las relaciones de mercado, por el capitalismo global, por las fuerzas bélicas, por los Estados, por la contemporaneidad. No es tradición. Es puro presente. Supervivencia.

Entonces ser pandillero o tener jerarquía no es por ser asesino, es por ver cómo hacés sobrevivir a tu pandilla en un ambiente que es hostil porque tenés a una sociedad y a un sistema de seguridad en tu contra y la misión es mantener tus soldados libres y vivos. Vivos sobreviviendo... o viviendo. ${ }^{49}$

La pandilla es una aparición dolorosa. Duele como tal y como síntoma de un sistema de sociedad. Duele en su origen, en el brinco doloroso, en el aguante del homeboy. La potencia de su contrapoder no está en la búsqueda de un ideal de cambio sino en el dolor que lo constituye. Va más allá de una ética del perdón y la compasión, en clave cristiana, como la lee Negri. Está en una ética del dolor y la violencia, de enlazarse con el dolor y la violencia, "en el momento mismo en que incluye el dolor, la potencia se abre a la comunidad y, finalmente, que esta apertura hace de la comunidad el asiento, no sólo de la legitimación de la ética, sino también del lugar de proyección futuro y redentor del hombre".${ }^{50}$ El dolor abre la comunidad, abre el portal, porque la comunidad pandillera es el umbral del dolor, infringido y padecido. El homeboy sabe que provocará dolor y le será provocado y es por el camino del dolor que pierde la compasión.

\footnotetext{
${ }^{46}$ Gorila, entrevista personal, junio 2009.

${ }^{47}$ Ibidem.

${ }^{48}$ Maffesoli, Michel, El tiempo de las tribus. El ocaso del individualismo en las sociedades posmodernas, México, Siglo XXI, 2004.

${ }^{49}$ Gorila, entrevista personal, junio 2009.

${ }^{50}$ Negri, Antonio, ob. cit., p. 162.
} 
Más allá de una ética y de un "lugar de proyección futuro y redentor del hombre", la pandilla se acomuna en los bordes. Su espacio está en el gueto de la globalización. En la exclusión el pandillero es contrapoder; no pretende "empoderamientos". Esta especie de cualidad terrible la expone Agamben así:

Esta naturaleza límbica es el secreto de Walser. Sus creaturas están irreparablemente extraviadas, pero en una región situada más allá de la perdición y de la salvación: su nulidad, de la que están orgullosos, es ante todo neutralidad respecto a la salvación, la objeción más radical que jamás se levantó contra la idea misma de redención. Propiamente insalvable es, desde luego, la vida en la que no se ve nada que salvar y contra ella naufraga la poderosa máquina teológica de la «oeconomia» cristiana [...] una impasibilidad límbica frente a la justicia divina. Como el condenado liberado en la colonia penal de Kafka, que ha sobrevivido a la destrucción de la máquina que debía ajusticiarlo, ellos han dejado atrás el mundo de la culpa y de la justicia. ${ }^{51}$

\section{HOMEBOY Y HOMEGIRL:}

\section{LA VIRILIDAD COMO RASGO COMUNITARIO}

La justicia del barrio se arma a partir de la amistad más allá del derecho, fuera de la ley. En ese sentido, el barrio es democrático, como aleccionó Gorila. Cada homeboy es importante en cuanto amigo y en cuanto soldado y está en la horizontalidad pandillera:

Pero si la amistad está por encima de la justicia - jurídica, política o moral-, ella es también, en consecuencia, la más justa. Justicia más allá de la justicia. Fraternidad como «derecho por encima del derecho». En todas las formas de gobierno o de constitución (realeza, aristocracia, timocracia, república o politeía - y la democracia como la menos mala de las constituciones «porque se desvía poco de la forma de la república»-) se ve aparecer una forma de amistad coextensiva con las relaciones de justicia. Y si, en la tiranía, la amistad y la justicia sólo juegan un papel muy débil, lo contrario pasa en la democracia, en la que domina, como hemos visto, la relación entre hermanos. ${ }^{52}$

El padre asesinado es la sociedad misma, pero una sociedad que los expulsó. El brinco resulta, además de ritual de pasaje, una puñalada al abandono, un acompañarse con los camaradas, con los realmente iguales, donde nadie

\footnotetext{
${ }^{51}$ Agamben, Giorgio, La comunidad que viene, Valencia, Pre-Textos, 2006, p. 14. Las cursivas son mías.

${ }^{52}$ Derrida, Jaques, Políticas de la amistad. Seguido del oído de Heidegger, Madrid, Trotta, 1998, p. 307.
} 
es más que el otro. Pero está igualdad puede desbordarse. La pandilla, para realizar su justicia, precisa de reglas, ordenamientos específicos de convivencia hacia dentro y hacia fuera. En lo que se refiere a las mujeres dentro de la pandilla, la situación de igualdad está disminuida. Todos afirman una igualdad, incluso Jipi, una pandillera calmada de la 18, lo hace:

Es igual a la de un hombre, pues. O sea que no hay discriminación hacia la mujer. Por lo menos en la pandilla de onde yo soy. Pero en la otra sí, como te digo, cada pandilla tiene su onda, pues, sus reglas. Entonces, pero una mujer es igual que un hombre. Los hombres lavan, planchan, hacen la comida, o sea que no es como lo maneja la gente, que las mujeres en una pandilla están para satisfacer a los hombres, que para hacerles la comida, que para cuidar los hijos, no, es igual, es igual. Como un hombre puede cocinar, puede lavar, puede hacer cosas igual que una mujer. ${ }^{53}$

Por su parte, Caz dice de las pandilleras: "Ellas, men, es el jardín del barrio. Las mujeres son como una rosa que tenemos plasmadas ahí, que están sembradas, que nos adornan, men. Muchas veces en el barrio estamos solos, men, la familia se nos corre o las mujeres de nosotros, pero las jainas de nosotros como son pactadas con nosotros siempre están ahí, men, están... ellas nos cocinan, nos lavan o algo pues siempre están para comprendernos, cabal". ${ }^{54}$ Entre jainas y mujeres está el pacto. Pero el rol social continúa: ellas cocinan, lavan, hacen lo que cualquier mujer, además del deber de mantener el honor del barrio. En ese sentido la homegirl no es igual al homeboy.

La pandillera realiza, con respecto al resto de la sociedad, una relación más estrecha definida por el rol. Otro pandillero de la 18, Sombra, explica: "La relación de una homegirl en la pandilla pues es común y corriente, se trata como a un hombre, sí, si ella misma lleva el mismo número que yo llevo, quiere decir que es una dieciochera, igual que mí, la única diferencia es el sexo, de ahí todo por igual. Participa de la misma manera que un hombre". ${ }^{55}$ Participar de la misma manera que un hombre significa realizar las "acciones" pandilleras en términos del honor y la venganza. Las homegirls, en su momento, se tatuaron con el mismo ahínco que los hombres (habrá que recordar que a partir de los planes Mano Dura y Súper Mano Dura, en El Salvador los pandilleros dejaron de tatuarse, lo cual dejó más vulnerables a quienes quedaron con el barrio rayado en la piel). Quizá dejen un poco

\footnotetext{
${ }^{53}$ Jipi, entrevista personal, junio 2008.

${ }^{54}$ Caz, entrevista personal, julio 2009.

${ }^{55}$ Sombra, entrevista personal, julio 2009.
} 
más de piel sin manchar, pero los rostros reciben con la misma ferocidad los números, portan el barrio.

"Desde luego, se incorpora a una pandilla, a la pandilla, es porque va a ser miembro dieciochera y va a hacer lo que en el barrio se dice. Idéntico, no hay ninguna discriminación o ninguna marginación por ser mujer. Con tal que porte el número quiere decir que es igual que mí, igual que los demás. Siempre que porte el número quiere decir que va a ser igual" ${ }^{56}$ La pandillera en la 18, a través de los rituales y las marcas, alcanza un estatus cercano al del homeboy. La homegirl se hace respetar. Pero la condición femenina (definida por la sociedad machista) las coloca en un hándicap frente a sus compañeros hombres, según la tensión hospitalidad-hostilidad, visible en lo concerniente a las relaciones amorosas:

Se respetan. Las relaciones amorosas se respetan y si ambos o alguno de los dos, por equis motivo pues le es infiel a... entre ambos son infieles, pues tienen su castigo, y tienen que pedir, por decir así, como un permiso o un pase, como se le pueda llamar, para poder volver a hacer otra relación con otra homegirl.

¿Qué castigo?

Una golpiza y un castigo que puede ser que no, por cierto tiempo, no se te permita tener roce con ninguna homegirl.

¿Y las relaciones con los civiles?

Para las mujeres están prohibidas. Para lo que son las homegirls sí, ellas sí no tienen ese permiso, esa autorización de tener un novio o un esposo civil.

¿Los hombres sí?

Los hombres sí

¿No que son iguales?

Somos iguales, pero, más que todo es por el respeto, a veces el trato, porque recuérdate que a veces nosotros los hombres sabemos a veces ser machistas. Entonces no te va a gustar a ti siendo un homeboy y una homegirl que la esté maltratando una persona civil, no te va a gustar.

\footnotetext{
${ }^{56}$ Ibídem.
} 
En cambio si ya es ya en lo que es la familia, ahí ya no habría mucho problema, porque las cosas se pueden arreglar. En cambio con una persona civil, como se dice se está faltando al respeto a la pandilla. ${ }^{57}$

La pandillera debe ganarse el respeto como cualquier otro, pero siempre es el respeto al barrio lo más importante. Esa sacralidad que Gorila reclamaba no la respetan quienes se borran el barrio. El barrio, aunque no esté sobre la piel, se respeta. Se asume, otra vez, un rol de condición femenina a la pandillera. Se le prohíbe emparentar con un civil para evitar la falta de respeto al barrio y, de esta manera, la supuesta igualdad entre homeboys y homegirls queda en el plano de la pertenencia.

Sin embargo, esta regla ha permitido a la 18 la integración de las mujeres en la comunidad pandillera. Son pocas en relación con los hombres, pero comparada con otras pandillas, la mujer participa más activamente. Incluso, respecto a la 18, la MS13 presenta una participación mucho más acotada de las mujeres, desde la forma en que son brincadas hasta la manera en que se les considera dentro del barrio.

La mujer tiene esa ventaja, de que no, no, porque no toda mujer tiene, cómo poderle decir, el valor de meterse, hoy la pandilla no confia mucho en la mujer. Por eso mismo, porque no tiene el valor, no tiene a veces el valor para, digamos, ir a matar a alguien, de ir a fregar a tal persona. Hoy no se siente tanto el apoyo de la mujer en la mara. ${ }^{58}$

Por otro lado, las pandilleras, con el hecho de brincarse, han conseguido una transformación respecto al resto de la sociedad. Una doble transformación o, por lo menos, un pasaje más doloroso, pues la violencia pandillera no las discrimina. La propia Jipi ha sido víctima de ésta, así como artífice. En el documental de Christian Poveda, ${ }^{59}$ aparecen homegirls en su vida cotidiana. En la secuencia de la fiesta, donde los pandilleros llevan al festejado una bailarina (que al parecer es civil) se nota en el contraste con las jainas una forma distinta de la mujer. La homegirl, por portar el número, es diferente a la mujer civil. Tanto como para padecer la misma violencia que los homeboys, mueren igual, se les despide igual, la deuda es igual, la venganza es igual. No sin la doble lucha, Jipi lo ve así:

Pero la mujer va peleando contra todo eso. Va peleando. Porque también hay un machismo, un feminismo dentro de las mujeres que

\footnotetext{
${ }^{57}$ Ibidem.

${ }^{58}$ Pay, entrevista personal, julio de 2009.

${ }^{59}$ Poveda, Christian, La vida loca, España, Francia y México, 1h, 29m, 2008.
} 
viven en la pandilla, tampoco, o sea, se dejan sumir tanto, verdad, son tan sumisas, como la demás población civil, que las mujeres tienen que hacer todo, verdad. Pero sí hay bastante machismo. No es de todos, son pocos, pero, sigue luchando la mujer contra eso, aparte que tiene que luchar, sufre también, verdad, la mujer en un rol de pandilla sufre una discriminación de la sociedad, que por ser mujer, ya son discriminadas, por ser pandilleras, doble... o sea, va doblemente discriminada, entonces tiene que luchar cada día, cada día para... contra esa discriminación, contra todos los obstáculos, a veces son madres solteras, que el esposo está preso [El esposo de H. estuvo preso y murió en una masacre dentro del penal, dejándola con dos niñas] y tiene que trabajar y tiene que... o sea, es muy cabrona la situación. ${ }^{60}$

El lugar de la mujer en la pandilla es, por designio machista, inamovible. En la pandilla se moviliza por la búsqueda de equiparación y respeto a través de la violencia. Deben mostrarse incluso más valientes. Doble presión, tanto del afuera de la pandilla como por la búsqueda del respeto. Las reglas que se le imponen van en pos de evitar las faltas al honor del barrio:

Pues como te he venido explicando, como fue a como es, hubo un periodo en la pandilla que era como un Sodoma y Gomorra. Entonces los grandes errores se convirtieron en grandes fortalezas, en juntos a fortalecer. Entonces, en ese aspecto la mujer formaron parte siempre de la pandilla y siempre por el machismo se le vio a la mujer como, no como un objeto sexual, sino como una mujer ahí, pero que no hacía las actividades de los demás, pero ella andaba en el grupo, pero a buscar su pareja, entonces para que no se anduviera con aquel problema de que era muy rebotona, que andaba con uno y con otro, se le cortó a las mujeres en la pandilla que anduvieran con varios. Entonces ella deja de andar con su pareja dentro de la pandilla, espera seis meses y vuelve a andar con otro. Depende el criterio de la comunidad donde ella esté. Yo soy de Tayni, hay de otras clicas. Entonces cada quien se atiene a su criterio, pero a ellas las van a respetar por sus acciones. Lo único que no tienen que pasarse es de la regla, ah va, hay una regla de la pandilla, pero también cada clica tiene sus reglas de convivencia, en lo que no hacer, lo que sí hacer, por ejemplo, en la pandilla no dice no, no hay que tomar licor, pero hay algunas tribus que no lo hacen, o lo hacen partidamente, la mitad sí, la mitad no y andan ahí regalándose porque los van a matar los contrarios, y otro montón de cuestiones. En las mujeres el ritual de iniciación es igual que en los hombres, otras

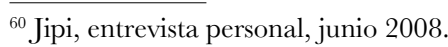


mujeres las tienen que brincar y es igual todo, es igual. Ahora, ellas tienen que ganarse sus méritos de igual manera, doblemente porque ellas ante los ojos de las demás y de los demás, en cambio los hombres por machismos, por como se le quiera ver, el hombre ya tiene ganada la mitad, que es no ganarse nada delante de ellas. Por machismo la mujer tiene que ganar al hombre, no el hombre a la mujer. Entonces, como irónicamente en la vida de esta, delictiva, si vos te fijás, a la mayoría de mujeres les gusta la gente que anda metido en cosas, que sean de banda, que sea de grupos, que sean de pandillas, aquí vas a ver pandilleros que andan con buenas mujeres, dos, tres, cuatro, preparadas, estudiantes, universitarias, profesionales, y ahí están y en algunos casos ellas los mantienen económicamente hablando. Entonces las mujeres pasan un ritual similar, pasan toda una actividad igual. Que sí se llegó a estigmatizar el hecho y por una teoría de asustar a las personas, decir que las mujeres eran sexualmente utilizadas y que si eras de la pandilla 18, 18 hombres tenían sexo con una mujer para... es mentira, y es mentira. Sí, la situación es de que hay cosas que son complicadas. Fíjate que, en la vida hay que saber elegir hasta tus amistades. Entonces en la pandilla andás cargando vos con muchas, no son secretos, sino ilegalidades, porque ser un pandillero es prácticamente una ilegalidad y entonces vos te relacionás, en mi caso, una cipota y yo de tonto le cuento todo lo que... a los días ella se enoja conmigo, nos peleamos, le doy duro, me pasé, sí, la golpeé, ah, tá bueno, la cipota fue a parar a la comisaría a decir todo, ahí está que ahí van cuarenta, cien bichos por la boca de ella, a los días ella muere, yo no le mande hacer nada, pero sí hubo una reacción a esa acción. ${ }^{61}$

La tensión hospitalidad-hostilidad se desborda en las relaciones amorosas de los pandilleros. La regla a las homegirls de no relacionarse con civiles va por el camino de evitar ofensivas contra la pandilla. En el caso de los homeboys, que libremente pueden mantener amoríos con mujeres civiles, la hostilidad está más presente que la hospitalidad. La regla refuerza el ostracismo pandillero para salvaguardar la hospitalidad. Sólo se es hospitalario de manera absoluta con quien decida dar el brinco; pero con los civiles la situación es de alto riesgo.

El enemigo, el enemigo de la moral en todo caso, es el amor. No porque sea enemigo, sino porque, en el exceso de atracción que desencadena, da lugar a la ruptura, a la enemistad, a la guerra. Lleva el odio consigo [...] El mal es el abandono: a sí mismo o al otro. Y esto empieza muy

\footnotetext{
${ }^{61}$ Gorila, entrevista personal, junio 2009.
} 
sencillamente, en el umbral, con el «sentimiento», desde la aparición del sentimiento o del afecto en general. Contra el abandono, una sola respuesta: «reglas» y «rígidas». ${ }^{6}$

La mujer busca respeto quizá con mayor ahínco en una sociedad que la excluye con mayor violencia que los hombres. Jipi dice de la relación entre pandilleros: "Hay doble respeto, hay más respeto: el respeto como pareja, el respeto como homeboys, verdad. Se maneja este respeto". ${ }^{63}$ Un respeto de igualdad inalcanzable fuera de la pandilla. Quizá por eso las pandilleras prefieran establecerse con un homeboy, quizá sea la prohibición. En todo caso, como repetidas veces me señalaron, cada clica define sus reglas, según la hostilidad enfrentada. Pero el nombre del barrio se respeta. Y al homeboy o homegirl se le respeta. Traicionar, herir o matar a un compañero se castiga. Por tanto, si dos dieciocheros son pareja, la pareja está envuelta por la comunidad y la igualdad es total.

Como te digo, si son pareja, se tienen que respetar de no... como si esta con otra mujer, verdad, que no sea de la pandilla, que a veces las maltratan y todo, verdad, entonces, cuando son pareja entre homeboys, se maneja el respeto de que no debe andar con otras mujeres. Es hombre, verdad, sabemos que los hombres siempre tienen otras mujeres y todo, pero tiene que tratar más esa cuestión, porque una mujer pandillera no aguanta carga. Y tampoco, o sea, si hay violencia entre los dos se tienen que ir formando ese respeto de que no haiga violencia, porque los dos son de la misma pandilla y tienen que respetarse en ese sentido, verdad, porque le están faltando el respeto al barrio, verdad. ${ }^{64}$

El barrio los confunde en cuanto pareja, antes de mantener una relación amorosa. Se pertenecen en cuanto homies. Sin embargo, la diferencia de géneros, la "condición femenina", aunque atemperada con la pertenencia al barrio, no se disuelve. Persigue a la homegirl y la hace mujer, es decir, débil, aunque no menos capacitada para la violencia. Si hay violencia hacia la mujer en una pareja de homies, la pandilla también tiene alguna cosa qué decir. Puede intervenir. "Es como vivir en tu comunidad ¿no? O sea, tú vives en una comunidad, tú te casas con alguien, pero, quiérase o no, siempre hay influencia comunal, verdad, para poder vivir en comunidad tienes que compartir con otras personas, nomás que no es lo mismo lo civil que dentro

\footnotetext{
${ }^{62}$ Derrida, Jaques, Políticas de la amistad... op. cit., p. 287.

${ }^{63} \mathrm{Jipi}$, entrevista personal, junio 2008.

${ }^{64}$ Pila, entrevista personal, junio 2008.
} 
del barrio, hay más respeto todavía", ${ }^{65}$ dice Pila, otro pandillero calmado de la 18. Si hay más respeto, la falta es doble: contra el miembro violentado y contra el barrio.

Si un homeboy tiene una pareja que no es de la pandilla y la golpea, la pandilla intervendría de manera "conciliadora", es decir, sin someter al infractor al peso de la regla (las reglas se hicieron para respetarse, o sino, morir, apunta Gorila), siempre buscando mantener el respeto al barrio. Jipi explica que "Puede a veces 'ey, qué te pasa, por qué la maltratás, no tenés que hacer eso', verdad. Porque hay muchos que respetan a la mujer, porque, 'yo tengo mi madrecita', o sea, por el respeto de que son criados por una mujer, verdad. Entonces, hay veces que han intervenido, que le llaman la atención, que no esté maltratando, y si tienen hijos que el ejemplo que le están dando a los hijos también, verdad. Pero, o sea, hasta ahí nomás, no pueden intervenir así al cien por ciento". ${ }^{66}$

El o la civil que mantiene relación con algún pandillero no se convierte, por esto, en parte del barrio, pues no ha hecho el pasaje, no se ha entrelazado a partir de sus líneas de fuga. El pacto doloroso debe signarse sin remilgos para que suceda el engarce comunitario, pues "acordémonos que como pandilleros siempre vamos a tratar de salvaguardar o ayudar a nuestros homeboys, porque por eso estamos... entonces se le dice que se calme o que entre en otra cordura, porque la jaina, quiérase o no, es libre, o sea, no es pandillera también, y él, pues se va a meter en controversias y puede meterse en problemas $y$ al meterse él en problemas, está metiendo en problemas con el barrio". ${ }^{67}$ Ella es libre cuando es civil (o él), no está atado al código de honor y respeto. No transitó a la comunidad pandillera, no se vincula con el lazo-de-deuda, no debe nada al barrio ni a los muertos por la "causa". Es profana y en ese registro una debilidad del cerco hospitalario. No existe la hospitalidad para el libre, el sin-lazo. Las relaciones amorosas con civiles tensan aún más la relación hospitalidad-hostilidad entre el barrio y el resto de la sociedad. No se es hospitalario con la pareja civil, pero tampoco hostil; se busca evitar el conflicto:

Hay un chingo de homegirls que tienen sus maridos y sus vatos de otra, que son civiles, pero es lo mismo, es lo mismo. O sea, al que se cuida más, desde la comunidad pandilleril, es al homeboy, al vato, pues también se le está chingando, pero entre hermanos y casados nadie mete sus manos. Pero si tanto es la necesidad de poder dialogar con alguien para que no meta al homeboy en problemas, entonces ahí "sabes qué,

\footnotetext{
${ }^{65}$ Ibidem.

${ }^{66}$ Jipi, entrevista personal, junio 2008.

${ }^{67}$ Pila, entrevista personal, junio 2008.
} 
vení, fijate que estás errando en esto tené cuidado, porque lo que va a pasar es que la das en la madre, te van a zampar seis meses preso y sos pandillero y tenés clavo o tenés alguna otra cosa te van a chingar tu vida, entonces, para que no pase eso agarra la onda, o la dejás o te... o sea, es tu problema, claro", porque él sabrá si la deja o no la deja, como te digo, cada quien se mete hasta donde puede incidir en eso, pero tampoco se mete de lleno porque respetan también la vida marital de las demás personas. ${ }^{68}$

Por el lado de la condición femenina, nunca perdida por la homegirl a pesar del pasaje, la violencia de pareja revienta la frialdad hospitalaria para tornarse en hostilidad frontal, debido a que "ahí es bien cabrón porque, ahí... o sea, son pareja, pero si hay una violencia intrafamiliar, los homeboys intervienen, pero también le está faltando el respeto al barrio". ${ }^{69}$ Además, el respeto a la pandilla inicia en el propio cuerpo del dieciochero, y una homegirl tiene como impronta hacerse respetar como miembro del barrio.

Pero acordate que está con una homegirl, y una homegirl está capacitada como para poder manejar sus propias... o sea, que antes de que llegue alguna situación hacia eso, ella ya tiene que haber arreglado sus problemas desde el principio o tiene que haber dado algo, antes de que vaya a tener como un pitazo y que llegue el barrio a intervenir. Entonces, esto es como una comunidad que se cuida, entre los miembros... tratamos la manera de que la hermandad siga firme ¿no? De un modo u otro, verdad, lo que se está tratando de ver es que los homeboys, como hermanos del barrio, ¿sí ves?, pues que no vaya a tener pedos, pues, se trata la manera de vivir lo más feliz que pueda. Pero con las condiciones en las que vivimos en nuestros países no cualquiera vive feliz. Tiene que andar chingándose a la vida para sobrevivir. Entonces, hay un motón de paradigmas que entran en acción que por sentido común tienes que irlos viendo, ahí nomás. O sea, es un sentido común de comunidad, nomás que tenemos más amor hacia nuestros miembros, verdad, así. Y la jaina tiene todo el derecho de defenderse, inclusive de los mismos homeboys. Si un homeboy está tratando de faltarle al respeto gacho y ésta tira como un pitazo "oye mira y este loco qué onda", entonces se habla con el homeboy: "mire homeboy, estás tratando con una homegirl, ¿ya?, no estás tratando con alguien raro, por decir algo, mantén la cordura ¿no?" ${ }^{70}$

\footnotetext{
${ }^{68}$ Ibidem.

${ }^{69}$ Jipi, entrevista personal, junio 2008.

${ }^{70}$ Pila, entrevista personal, junio 2008.
} 
Hay un doble aparejo del respeto, el que da al afuera del barrio, el que debe mantenerse y buscarse con la venganza y el que debe mantenerse en el pacto. El respeto hacia la homegirl por los homeboys y entre ellos en términos de hermandad, del lazo-de-deuda. El barrio es comunidad en cuanto hermandad sin padres, pero con la presencia de la familia institucional. El pandillero no se va del vecindario, salvo cuando escapa del enemigo mortal, cuando se ha brincado a una pandilla que no territorializa el lugar de origen, la colonia donde vive. Por tanto, hay sensibilidad del afuera hospitalario, los vecinos y familiares, las parejas civiles. Pero la hermandad pandillera no incluye esa conexión con el afuera. El respeto se busca, se cultiva, el pandillero se perfila para ser respetado a partir de los honores proveídos a la pandilla. Así, la hospitalidad absoluta para el "hermano" sólo es posible a partir del lazo de deuda. No permite la entrada de quien no ha dado el brinco.

No se tiene amistad por el padre, no se tiene amistad por lo que hace posible la amistad. Se le tiene reconocimiento, puesto que se está obligado a él. Hay incluso amor reciproco con el padre, pero este amor recíproco (no igual) no es una amistad. A la amistad le hace falta respeto no sólo recíproco sino igual de una parte y otra. Imposible con el padre, posible solamente con los hermanos, con lo que se representa como hermanos. ${ }^{71}$

\section{A MANERA DE CONCLUSIÓN}

Si hay algo que estructura a la pandilla es la pertenencia, lo que convierte a la venganza en el principal motor de la violencia. Esto se inscribe en un marco de honorabilidad desde donde se definen las reglas: defender al barrio y a los homeboys. De ahí que una de las transgresiones más deleznables para los miembros del grupo sea la traición, porque a partir de ésta se fisura la protección hospitalaria que les permite un umbral de supervivencia más o menos de amplio espectro.

Es por esto que las principales estrategias para afrontar el fenómeno por parte del gobierno salvadoreño tienen como principio elevar el nivel de hostilidad del resto de la sociedad a la pandilla, como sucedió en 2010. La ley de proscripción de pandillas buscó limitar las relaciones de los pandilleros con organizaciones civiles. Más grave aún, en la declaratoria en 2015 de las pandillas como grupos terroristas se pena cualquier tipo de relación con las pandillas, incluso la "apología", lo cual sigue sin ser del todo claro en el caso de estas agrupaciones.

${ }^{71}$ Derrida, Jaques, Políticas de la amistad..., op. cit., p. 292. 
El objetivo de este artículo no es apologético. No se trata de observar en la violencia de las pandillas una forma legítima de relacionarse socialmente. Se trata de comprender, más allá de simplificaciones criminalizantes, la potencia de las pandillas para acoger a miles de jóvenes marginados.

¿Por qué estos jóvenes eligen entrar a las pandillas? ¿Qué les ofrece? Este artículo observa una pequeña parte del fenómeno, lo que he llamado lazode-deuda como posibilidad de pertenencia, de hermandad. Ser parte de algo, tener un gramo de poder y respeto es lo que la pandilla ofrece. Algo que las instituciones de la sociedad les ha negado debido al sistema de sociedad incapaz de brindar opciones vitales a millones de personas, en particular a los jóvenes, sobre todo en El Salvador, donde el término "juvenicidio" parece tener cabida.

Esa pertenencia que ofrece la pandilla tiene un costo que los jóvenes pagan sin gran reflexión, sólo como expresión de su formar parte, como miembros de una comunidad emergente en este sistema capitalista en su fase superior. En ese carácter de comunidad existe una potencia para crear y escapar de la destrucción y la violencia. El drama está en que si se sigue tratando a las pandillas como un fenómeno exclusivamente criminal, ese potencial creador será abortado. Quedará sólo una amplificación de la capacidad mortífera de esos grupos. Esto ya se está observando en El Salvador y otros países centroamericanos. Las respuestas de los pandilleros, cuando quieren ofrecer algo más que violencia (como la tregua de 2012-2014), han recibido desprecio y ellos han reaccionado con mayor violencia.

A principios de 2017 la MS ofreció diálogo:

Mara Salvatrucha pide hoy un diálogo cuya agenda pueda incluir la desarticulación de la pandilla, lo que implica un giro radical a la postura de hace cuatro años, cuando la cúpula nacional rechazó siquiera hablar de su posible desmontaje. Tres voceros de la organización criminal expusieron a El Faro una propuesta para discutir soluciones al problema de violencia en una mesa de negociación pública que incluya al gobierno y a todos los partidos políticos. El vocero de la Presidencia, Eugenio Chicas, dice que es una propuesta "a la que hay que darle taller". ${ }^{72}$

La violencia ha llegado a niveles insostenibles, tan brutales que las propias pandillas estarían en condiciones de disolverse antes de autodestruirse. Todavía falta mucho para observar cuáles son los resultados de las políticas criminales que ha tomado el actual gobierno salvadoreño, pero sus efectos inmediatos siguen siendo de enorme violencia.

\footnotetext{
${ }^{72}$ Martínez, Carlos y Valencia, Roberto, "MS-13 pide diálogo al gobierno y pone sobre la mesa su propia desarticulación”, elfaro.net, 9 de enero de 2017 [Consulta: 23 de enero de 2017]. Disponible en: https:// elfaro.net/es/201701/salanegra/19747/MS-13-pide-di\%C3\%A1logo-al-gobierno-y-pone-sobre-la-mesa-su-propia-desarticulaci $\% \mathrm{C} 3 \% \mathrm{~B} 3 \mathrm{n} . \mathrm{htm}$
} 


\section{REFERENCIAS}

Agamben, Giorgio, La comunidad que viene, Valencia, Pre-Textos, 2006.

Appiolaza, Martín, "Criminología cultural y el trabajo con grupos juveniles violentos como actores sociales del cambio", en Joaquín A. Mejía Rivera, C. H. Gerardo Ballesteros de León y Josué Murillo (coords.), Violencia, Derechos Humanos y Seguridad Ciudadana, Tegucigalpa, Casa San Ignacio - Guaymuras, 2014.

Bauman, Zigmunt, Globalización, consecuencias humanas, México, Fondo de Cultura Económica, 1999.

Bengoa, Valdés Ana, "De maras a marabuntas. El miedo como dispositivo gubernamental, una lectura desde El Salvador", Polis, Revista Latinoamericana, vol. 14, núm. 42, 2015.

Brotherton, David y Barrios, Luis, The Almighty Latin King and Queen Nation: street politics and the transformation of a New York City gang, Nueva York, Columbia University Press, 2004.

Cerbino, Mauro, "La nación imaginada de los Latin Kings, mimetismo, colonialidad y transnacionalismo", tesis de Doctorado, Tarragona, 2009.

Cerbino, Mauro, El lugar de la violencia. Perspectivas críticas sobre pandillerismo juvenil, Quito, Ecuador, Taurus, 2012.

Clastres, Pierre, La sociedad contra el Estado, Barcelona, Monte Avila, 1978.

Derrida, Jaques, El siglo y el perdón. Seguido de Fe y saber, Buenos Aires, Ediciones de la flor, 2006.

Derrida, Jaques, Políticas de la amistad. Seguido del oído de Heidegger, Madrid, Trotta, 1998.

Esposito, Roberto, Immunitas. Protección y negación de la vida, Buenos Aires, Amorrortu, 2005.

Esposito, Roberto, Tercera persona. Política de la vida y filosofia de lo impersonal, Buenos Aires, Amorrortu, 2009.

Feixa, Carles y Canelles, Noemi, "De bandas latinas a asociaciones juveniles: La experiencia de Barcelona", Educação (Porto Alegre), vol. 30, núm. 1.

Feixa, Carles, Fóvenes 'latinos' en Barcelona. Espacio público y cultura urbana, Barcelona, Anthropos, 2006.

Feixa, Carles, De jóvenes, bandas y tribus, Barcelona, Ariel, 1998.

Gomezjara, Francisco, La banda en tiempo de crisis, México, Ediciones Nueva, 1987.

López, Fuentes Daniel, Las pandillas: Su expansión territorial en El Salvador: 1992-2015, San Salvador, El Salvador, Colegio de Altos Estudios Estratégicos, 2017.

Maffesoli, Michel, El tiempo de las tribus. El ocaso del individualismo en las sociedades posmodernas, México, Siglo XXI, 2004.

Martínez, Carlos y Valencia, Roberto, "MS-13 pide diálogo al gobierno y pone sobre la mesa su propia desarticulación", El Faro, 9 de enero, 2017. [Consulta: 23 de enero, 2017]. Disponible en: https://elfaro.net/es/201701/salanegra/19747/ MS-13-pide-di\%C3\%Allogo-al-gobierno-y-pone-sobre-la-mesa-su-propiadesarticulaci $\% \mathrm{C} 3 \% \mathrm{~B} 3 \mathrm{n} . \mathrm{htm}$

Moreno, Hugo César, "La vida en contra: apuntes para una teoría sobre el fenómeno de las pandillas transnacionales en El Salvador", Revista Internacional de Investigación y Docencia, núm. 1.

Moreno, Hugo César, Pandillas transnacionales en El Salvador y Ecuador: criminalización versus integración, Buenos Aires, Clacso, 2014. 
Moreno, Hugo César y Sánchez, Mónica Elivier, "Pandilla 18 y Mara Salvatrucha 13: Violencia y desciudadanización", Revista Cultura-Hombre-Sociedad, vol. 22, núm. 2.

Moreno, Hugo César y Sánchez, Mónica Elivier, Homies Unidos: Estrategias de reestratificación desde la sociedad civil, México, Universidad Iberoamericana, 2018.

Murcia, Walter, Las pandillas en El Salvador. Propuestas y desafios para la inclusión social juvenil en contextos de violencia urbana, México, CEPAL, 2015.

Nateras, Domínguez Alfredo, Vivo por mi madre y muero por mi barrio: Significados de la violencia y la muerte en el Barrio 18 y la Mara Salvatrucha, México, UAM - Tirant Humanidades, 2015.

Navidad Guillén, Jaime Antonio, Los postconflictos: estabilización y construcción de la paz. Caso de estudio El Salvador, San Salvador, El Salvador, Colegio de Altos Estudios Estratégicos, 2017.

Negri, Antonio, Fob: la fuerza del esclavo, Buenos Aires, Paidós, 2003.

Perea Restrepo, Carlos Mario, Con el diablo adentro. Pandillas, tiempo paralelo y poder, México, Siglo XXI, 2007.

Poveda, Christian, La vida loca, España, Francia y México, 1h, 29m, 2008.

Sampó, Carolina, "El rol de las mujeres en las maras: una aproximación a la violencia que sufren e infringen", Si Somos Americanos. Revista de Estudios Transfronterizos, vol. 16, núm. 2.

Reguillo, Cruz Rossana, "La mara: contingencia y afiliación con el exceso (re-pensando los límites)", en José Manuel Valenzuela Arce, Alfredo Nateras Domínguez y Rossana Reguillo Cruz (coords.), Las Maras: identidades juveniles al límite, México, UAM - Colef - Juan Pablos, 2007.

Reguillo, Gruz Rossana, En la calle otra vez. Las bandas: identidad urbana y los usos de la comunicación, Guadalajara, Iteso, 1991.

Rivera, César, "Crimen organizado y maras: el nudo gordiano salvadoreño", en Carlos Basombrío (ed.), ¿A dónde vamos? Análisis de políticas públicas de seguridad ciudadana en América Latina, Estados Unidos, Woodrow Wilson International Center for Scholars, 2013.

Thrasher, Frederic Milton, The Gang. A Study of 1313 Gangs in Chicago, Chicago, University of Chicago Press, 1963. 